\title{
Initial investigation of the intrinsic geomechanical properties of soils in area of landslide Černá Pole
}

\author{
Karolína Faktorová ${ }^{1}$, Juraj Chalmovský², Pavel Koudela ${ }^{3}$, Lumír Míča ${ }^{4}$ \\ University of Technology, Faculty of Civil Engineering, Institute of Geotechnics, Brno, Czech Republic \\ E-mail: ${ }^{1}$ karolinafaktorova@gmail.com (corresponding author)
}

\begin{abstract}
One of the most important type of Brno's subsoil is Miocene's clay. Mechanical properties of these clays were already studied by various methods, authors, in several locations. These parameters, however, varies across the locations and therefore new data are needed to further refineme them. The objective of the laboratory tests presented in this paper was to determine shear strength and compressibility parameters on reconstituted samples, locality Cerná Pole. Stiffness parameters for primary loading and unloading - reloading were obtained from series of oedometer tests. Consolidated undrained triaxial tests were performed for evaluation of soil critical shear strength. Obtained results were compared with another available data.
\end{abstract}

Keywords: oedometer test, triaxial test, internal friction angle, Brno Clay, econstituted samples.

\section{Introduction}

The Early Baden clay called "tegl" is a typical subsoil in the city of Brno as well as in Carpathian basin. This sequence had been formed in the Middle Miocene period. They are calcium reach, unlayered, marine clays, sedimented during the transgression at the area of deeper basins. Mechanical properties of Brno Clay was studied many times showing certain scatter in the obtain results. Shear strength parameters were studied by Boháč (1999), Uhrin (2004), Erbenová (2008), Svoboda (2010) and Fencl (2012). Boháč (1999) investigated data from the Boby centrum locality (Figure 1, “A”), while Svoboda (2010) and Fencl (2012) examined clays from VMO Dobrovského (Figure 1, "B”). Pavlová $(2011,2014)$ tested clays from Královo Pole tunnels (Figure 1, "B"). Hyrman (2009) performed a slope stability analysis in the location of Medlánky landslide (Figure 1, "C"). His researche followed the work of Poul and Koubová (2008), whose obtained critical state angle during their analysis on the same location. The structure of clay was studied on several locations by Kazda (1968). Uhrin (2004) applied a Cam Clay model on the Brno Clay, Ponávka location (Figure 1, "D"). Brno Clay is standardly classified as overconsolidated soil (Mencl, 1966 and Erbenová, 2008). Two processes leading to overconsolidation are distinguished: mechanical unloading due to denudation and creep effects (pseudo-overconsolidation). This phenomenon was studied by Malát (2017).

The aim of this study was to determine the intrinsic compressibility and shear strength parameters based on a series of oedometric and triaxial tests. Reconstituted specimens were prepared from disturbed soil samples, location Brno - Černá Pole (Figure 1, “E”). Including tests from another location extend the available exploration of Brno Clay.

\section{Methods}

Laboratory tests were performed on reconstituted samples. Suitable material was obtained from an area of Černá Pole landslide. Sampling depth was between 28 and $30 \mathrm{~m}$. Based on the particle size distribution curve, obtained soil samples were classified according to ČSN EN ISO 14688-2 as Clay $(\mathrm{Cl})$. The calculated values of the plastic limit $P L$ and liquid limit $L L$ were 34.3 and $63.9 \%$, respectively. All samples were created as slurries by mixing the soil with water at the initial water content $w_{i}$ of $75 \%$. Burland (1990) recommended that slurried samples should be prepared at water contents between 1 and $1.5 \mathrm{LL}$.

\section{One-dimensional compression tests}

Five one-dimensional consolidation tests were carried out. The diameter and height of the samples were 50 and $20 \mathrm{~mm}$, respectively. The average duration of each test was 20 days. The incremental loading procedure was performed, with a hold period of 24 hours at each stress level. The following loading sequence was used: 5, 10, 20, 40, 60, 100, 


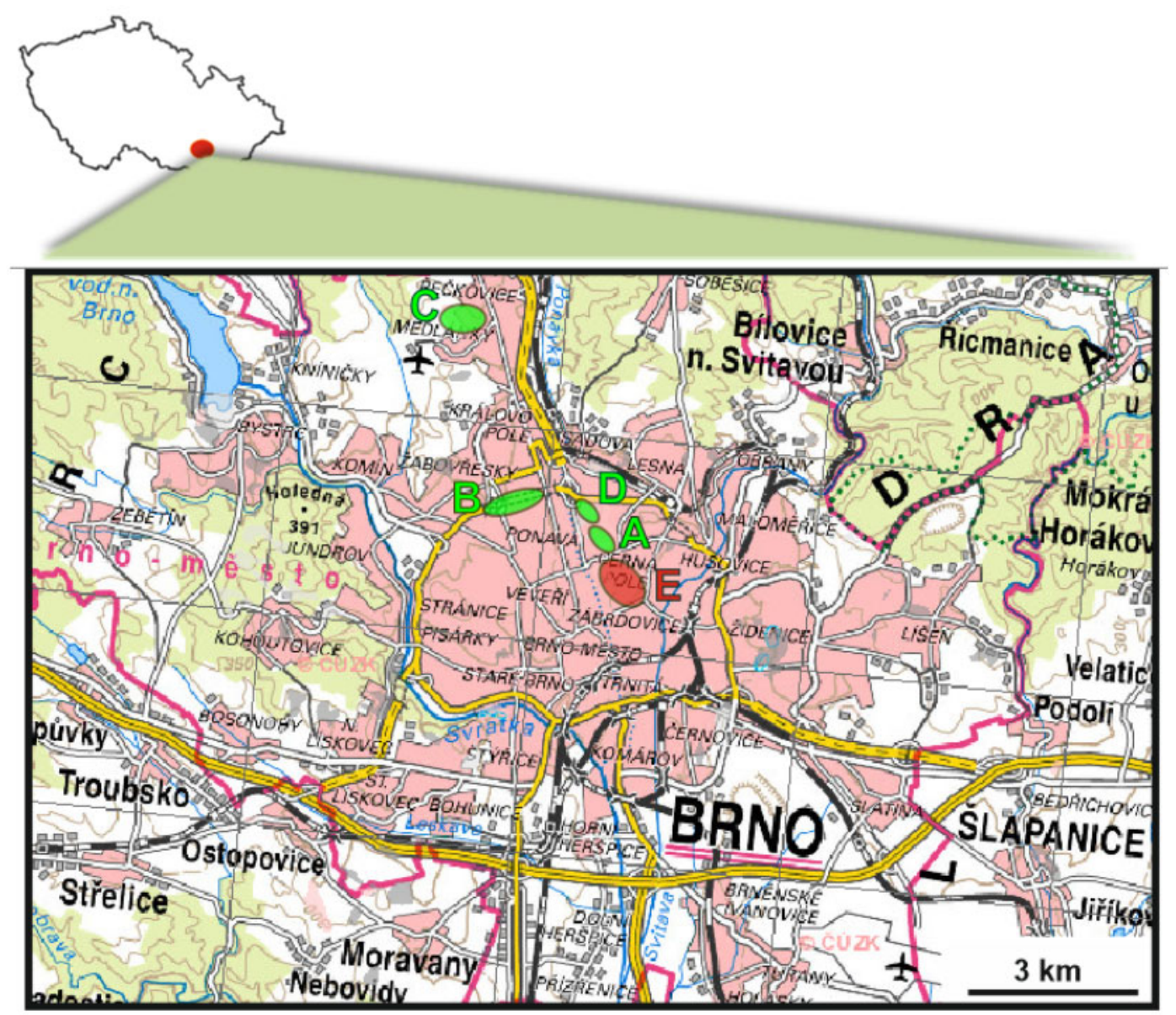

Figure 1. Discussed Localities of geomechanical analysies on Miocene Brno Clay

$150,200,400,800$ and $1000 \mathrm{kPa}$. After reaching the ultimate load, step-wise unloading was performed. The same load levels and hold periods as in primary loading were used. Final sample heights and the water contents were determined after each test had been completed. Test results were primarily evaluated in the $e-\log \sigma^{\prime}$ space, where $\sigma^{\prime}$ is the vertical effective stress and $e$ is the void ratio. Values of the intrinsic compression index $C_{c}^{*}$ and the intrinsic recompression index $C_{r}^{*}$ defying the slope of the intrinsic normal compression line (NCL*) and the intrinsic unloading - reloading line (URL*) were evaluated. Alternatively, the $\ln (1+e)-\ln p^{\prime}$ plot was used with the optional parameters $\lambda^{*}$ and $\kappa^{*} . K_{0}=1-\sin \varphi_{c s}^{*}$ was considered here in order to calculate the effective mean stress $p^{\prime}, \varphi_{c s}^{*}$ is the intrinsic critical state angle of internal friction derived from triaxial tests described in the following chapter.

\section{Triaxial compression tests}

The testing program consisted of three $\mathrm{CU}$ triaxial tests with measurement of pore pressures. Slurry samples were placed in steel tubes with the inner diameter of $38 \mathrm{~mm}$ (Figure 2). The steel tubes were then enclosed in triaxial cells and filled with water followed by incremental loading up to the load level of $100 \mathrm{kPa}$. The tubes were removed after that from the triaxial cells and samples were carefully extruded and cut to the prescribed height of $76 \mathrm{~mm}$. A sample prepared as described above was measured, weighted and fitted in another triaxial cell in which CU tests were conducted. The samples were isotropically consolidated up to the mean effective stress $p_{0}=200,400,800 \mathrm{kPa}$, no overconsolidation was simulated. After stabilized of volume changes during the consolidation stage, the shearing stage followed. Deviatoric loading was performed at the constant rate of axial deformation $0.0035 \mathrm{~mm} / \mathrm{min}$. The strain rate was calculated according to ČSN CEN ISO/TS 17892-9 considering that drainage is allowed both from a bottom surface and a sample surface. The strain rate was further reduced in order to ensure equalization of excess pore pressures generated throughout the specimen during shearing. The average duration of each test was 1,5 week (without sample preparation). $\varepsilon_{a}-q, \varepsilon_{a}-u$ plots and effective stress paths were evaluated in which $\varepsilon_{a}$ is the axial strain, $q$ is the deviatoric stress and $u$ is the excess pore pressure. Finally, the intrinsic critical state angle of internal friction was determined. 


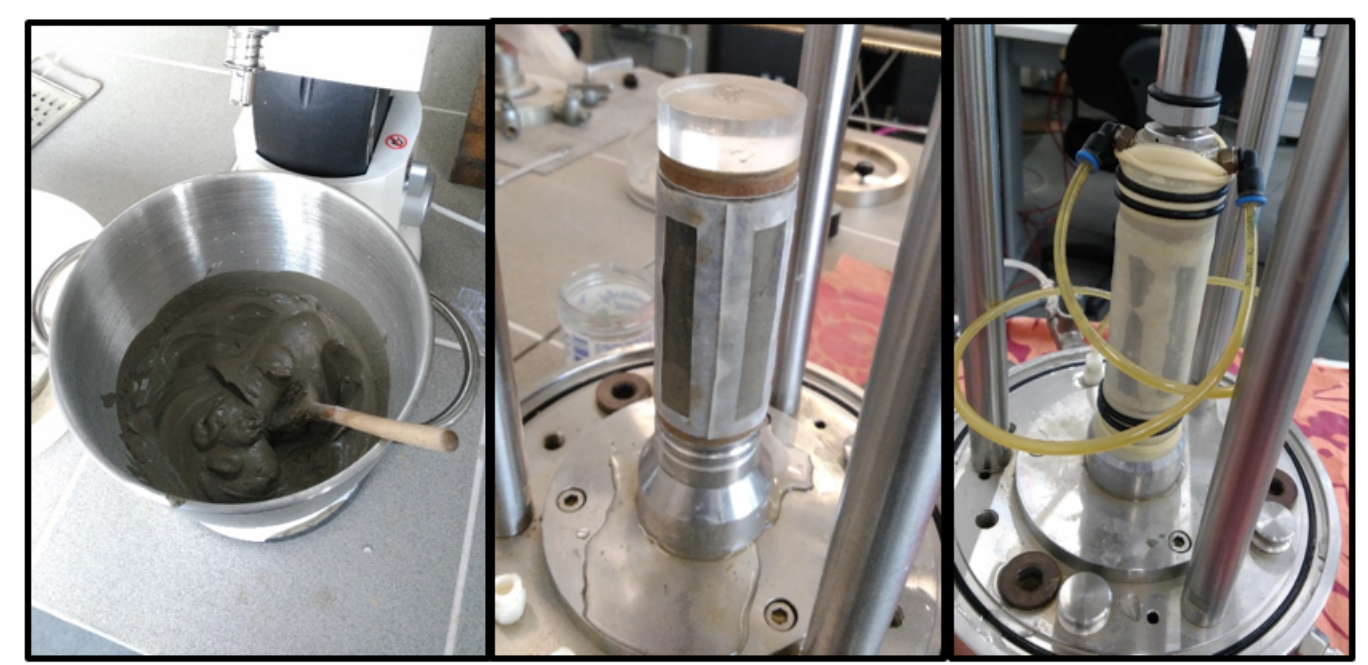

Figure 2. Process of preparation the TRX samples

\section{Results and discussion}

One-dimensional compression tests

Compressibility indexes for each test are given in Table 1 . The average values of $\lambda^{*},{ }^{*}$ and $C_{c}, C_{r}$ were 0.085 , 0.016 and $0.438,0.074$, respectively. Data from all tests are presented in Figure 3 in the $e-\log \sigma^{\prime}$ plane.

Table 1. Parameters of compressibility

\begin{tabular}{|c|c|c|c|c|}
\hline & $\lambda^{*}$ & $\mathbf{K}^{*}$ & $\mathbf{C}_{\mathbf{c}}{ }^{*}$ & $\boldsymbol{C}_{\boldsymbol{r}}{ }^{*}$ \\
\hline EdoI & 0.0792 & 0.0161 & 0.407 & 0.0697 \\
\hline EdoII & 0.0837 & 0.0156 & 0.4258 & 0.0674 \\
\hline EdoIII & 0.0844 & 0.0157 & 0.4543 & 0.0719 \\
\hline EdoIV & 0.0854 & 0.0172 & 0.4593 & 0.079 \\
\hline EdoV & 0.0919 & 0.017 & 0.5056 & 0.0776 \\
\hline Minimum & 0.0792 & 0.0156 & 0.407 & 0.0674 \\
\hline Maximum & 0.0919 & 0.0172 & 0.5056 & 0.079 \\
\hline Average val. & $\mathbf{0 . 0 8 4 9}$ & $\mathbf{0 . 0 1 6 3}$ & $\mathbf{0 . 4 5}$ & $\mathbf{0 . 0 7 3 1}$ \\
\hline Standard dev. & $\mathbf{0 . 0 0 4 5 7}$ & $\mathbf{0 . 0 0 0 7 4}$ & $\mathbf{0 . 0 3 7 5 2}$ & $\mathbf{0 . 0 0 5 0 1}$ \\
\hline
\end{tabular}

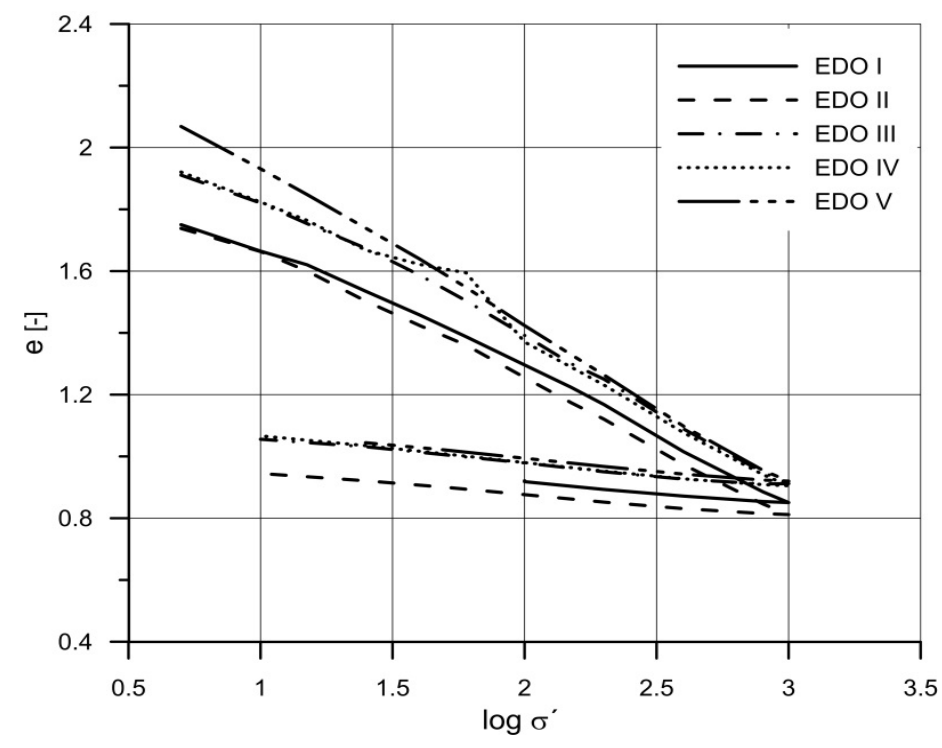

Figure 3. Soil behaviour during one-dimensional compression 
The scatter in the initial void ratios was observed, however, shapes of the compression lines and the compression indexes are similar. Obtained inclinations of NCL* are about a third smaller than the results $\left(\lambda^{*}=0.128\right)$ reported by Svoboda (2010). On the contrary, his value of the URL* inclination is less $\left(\kappa^{*}=0.01\right)$ than those presented in this study. Higher values of the compressibility parameters $\left(\lambda^{*}=0.252, C_{c}=0.58, \kappa^{*}=0.09, C_{r}=0.13\right)$ were reported by Uhrin (2004). Author suggest, that the resulting values depend on different mineralogical composition of studied samples.

\section{Triaxial compression tests}

The results from three consolidated undrained triaxial tests with measurement of pore pressures are presented in this chapter. The $q-\varepsilon_{a}$ and $\Delta u-\varepsilon_{a}$ plots are given in Figure 4 and 5, respectively. Effective stress paths and the Mohr-Coulomb failure line corresponding to the $\varphi_{\mathrm{cs}}{ }^{*}=25.5^{\circ}$ are shown in Figure 6 . In all samples, no overconsolidation behavior was simulated before shearing. Effective stress state is reduced during the process of shearing due to development of excess pore pressure and thus bending the effective stress paths to the left. During the last test, a malfunction occurred causing an interruption of the test record. At this stage, excess pore pressures were not completely stabilized. Despite this, it is possible to assume that the test was close to the critical state. Remaining two tests at lower cell pressures reached the critical state without any obstacles.

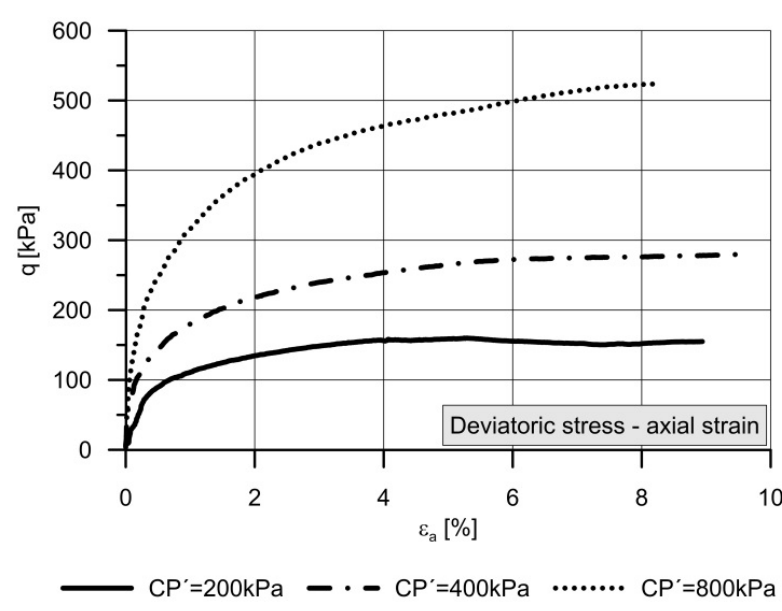

Figure 4. Dependency of $q-\varepsilon_{\mathrm{a}}$

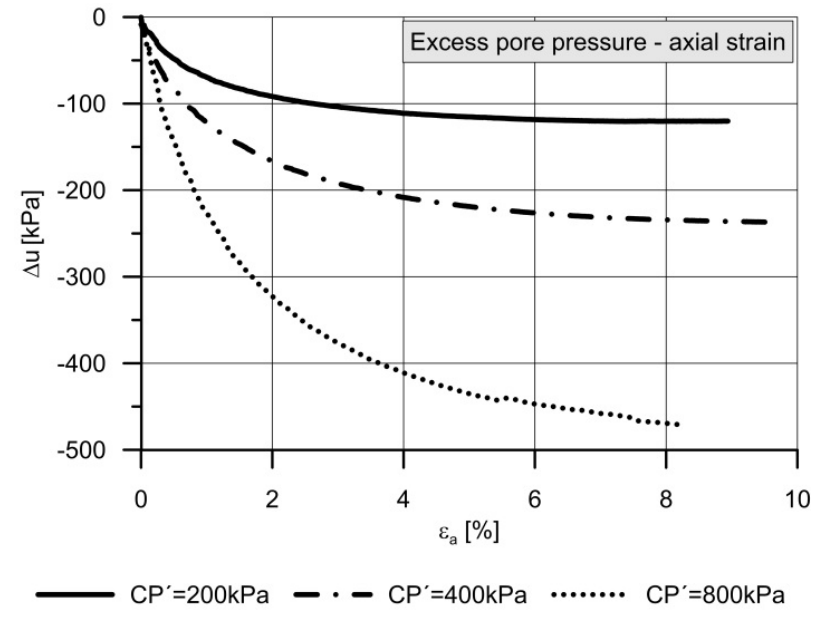

Figure 5. Dependency of $\Delta u-\varepsilon_{a}$

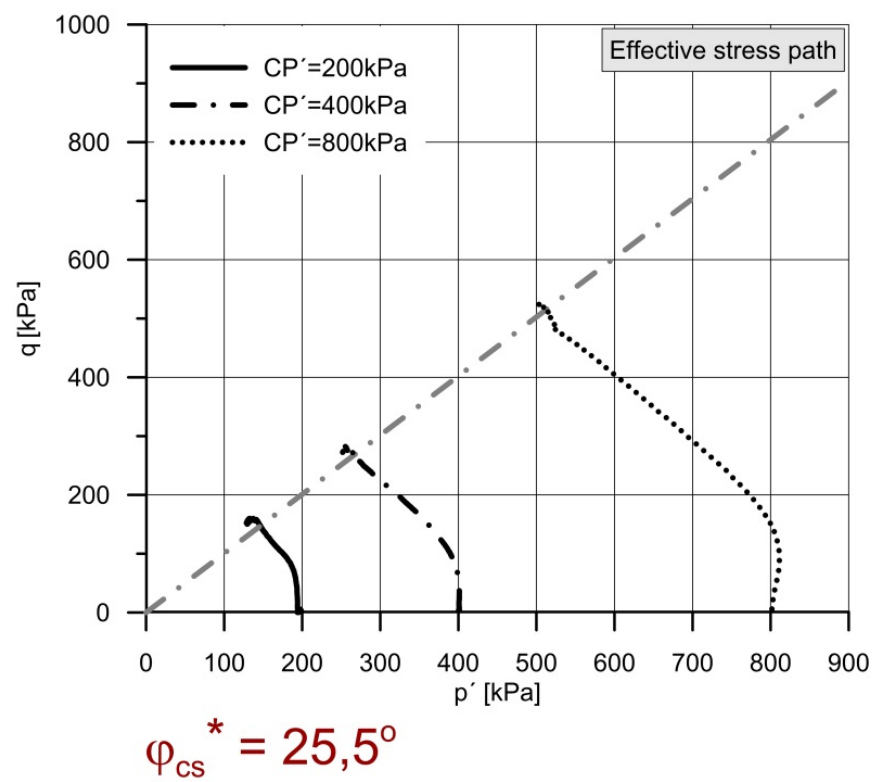

Figure 6. Effective stress paths 
Najser and Boháč (2005) determined the value of $\varphi_{\mathrm{cs}}{ }^{*}=19.8^{\circ}$ using a ring shear test apparatus. Svoboda (2010) performed the triaxial test on the reconstituted sample at a high level of confining pressure $(2550 \mathrm{kPa})$ giving the value of $\varphi_{\mathrm{cs}}{ }^{*}=18.9^{\circ}$. Fencl $(2012)$ recommended the value of $\varphi_{\mathrm{cs}}{ }^{*}=19.8^{\circ}$ and $23.5^{\circ}$ based on ring shear tests and triaxial tests with sliding plates, respectively. The triaxial tests were conducted at confining stress levels between 50 and $300 \mathrm{kPa}$. He also found out that without the use of sliding plates, the critical state angle of internal friction was lower $\left(\varphi_{\mathrm{cs}}{ }^{*}=21.0^{\circ}\right)$. Given the range of confining stresses and application of the upper and lower sliding plates the $\varphi_{\mathrm{cs}}{ }^{*}$ value derived in this paper is closest to the triaxial test results with sliding plates performed by Fencl (2012). The comparison with previously mentioned tests suggests that the critical shear strength might be underestimated during standard triaxial tests when no sliding plates are used due to occurrence of local shear planes. No visible sign of strain localization was observed during the tests presented here. According to Fencl (2012), significantly lower value of $\varphi_{\mathrm{cs}}{ }^{*}$ obtained by Svoboda (2010) at the high cell pressure might indicate curvature of the failure line. Although Svoboda (2010) and Boháč (1999) tested Brno Clay, the mineral composition was different. Svoboda's (2010) samples contained about 5\% of caolinite, whereas Boháč's (1999) clays contained almost $23 \%$ of the mineral.

\section{Conclusions}

A series of one - dimensional compression tests and consolidated undrained triaxial tests with measurement of pore pressures performed on reconstituted samples of Brno Clay was presented in this paper.

Oedometer tests in this paper, exhibit similar behavior in terms of the compressibility indexes for loading and unloading. Location of NCLs is however different due to variability in the initial void ratio.

The value of intrinsic internal friction angle in the critical state is closest to the triaxial test results obtained by Fencl (2012) in which sliding plates were used as well as in this case. However, in comparison with other authors, the obtained results show some differences. Possible reasons might be found in: different mineral composition Boháč (1999) and different range of cell pressures (Fencl, 2012) and (Svoboda, 2010).

Main objectives of further tests which are currently and will be performed are: to determine intrinsic properties of Brno Clay from current and greater depths, to analyze an influence of the initial water content, to perform undrained and drained triaxial test on overconsolidated samples.

\section{Acknowledgements}

This paper has been worked out under the project "AdMaS UP - Advanced Materials, Structures and Technologies" [grant number LO1408], supported by Ministry of Education, Youth and Sports under the "National Sustainability Programme I".

\section{References}

Boháč, J. (1999). Pevnost a přetváření brněnského téglu, Strength and deformations of Brno Clay. In XI International Scientific Conference (pp. 33-36). Technical University VUT, Brno (in Czech).

Burland, J. B. (1990). On the compressibility and shear strength of natural clays. Geotechnique, 40(3), $329-378$. https://doi.org/10.1680/geot.1990.40.3.329

Český normalizační institut. (2005). Geotechnický průzkum a zkoušení - Laboratorní zkoušky zemin - část 9: Konsolidovaná triaxiální zkouška vodou nasycených zemin, 16 (ČSN CEN ISO/TS 17892-9). Praha.

Český normalizační institut. (2018). Geotechnický průzkum a zkoušení - Pojmenování a zatřid'ování zemin - Část 2: zásady pro zatřid'ování, 16 (ČSN EN ISO 14688-2). Praha.

Erbenová, A. (2008). Př́spěvek k charakteristice mechanického chování miocénních jílů jako základové půdy na Moravě. Geotechnika, 2008(3), 28-31. Praha.

Fencl, M. (2012). Pevnost brněnského téglu v kritickém stavu (MS: Diplomová práce). Univerzita Karlova. Praha.

Hyrman, J. (2009). Posouzeni stability svahu jílovitých zemin (Brno - Medlánky) (MS: Bakalářská práce). Masarykova univerzita. Brno.

Kazda, J. (1968). Studium strukturnosti systému: jílová zemina - voda. In A. Myslivec (Ed.), Ílovité zeminy a ich použitie v stavebnictve. Vydavatelstvo SAV, Bratislava (in Czech).

Malát, R. (2017). Určeni mocnosti eroze brněnského téglu (MS: Disertační práce). Univerzita Karlova, Praha.

Mencl, V. (1966). Mechanika zemin a skalních hornin. Academia, Praha.

Najser, J., \& Boháč, J. (2005). Pevnost zemin v kritickém stavu v torzním krabicovém př́istroji. In Weiglová, K., Sborník přispěvkỉ 33. Konference Zakládáni staveb (pp. 37-42). Brno.

Pavlová, M. (2011). Mocnost nadloži překonsolidace brněnského jílu (MS: Bakalářská práce). Univerzita Karlova, Praha.

Pavlová, M. (2014). Sekundárni stlačitelnost brněnského téglu (MS: Diplomová práce). Univerzita Karlova, Praha.

Poul, I., \& Koubová, E. (2008). Mechanické vlastnosti překonsolidovaných jílů v brněnské aglomeraci. Sekurkon, Zakládáni stveb, 36, 137-142. Brno.

Svoboda, T. (2010). Numerický model NRTM tunelu v tuhém jílu (MS: Disertační práce). Univerzita Karlova, Praha.

Uhrin, M. (2004). Aplikace Cam Clay modelu na brněnský jíl (MS: Diplomová práce). Vysoké učení technické, Brno. 